\title{
FILOSOFÍA, INTERTEXTUALIDAD Y POSTMODERNISMO: LA INFLUENCIA DE FRIEDRICH NIETZSCHE EN LA OBRA NOVELÍSTICA Y EN LA ENSAYÍSTICA DE JUAN BENET
}

\author{
Jorge MACHÍN LUCAS \\ University of Winnipeg \\ jorgemachin@yahoo.es
}

\begin{abstract}
Tal ha sido durante siglos el tema fundamental de la filosofía: el inventario de una conciencia a la que poco a poco, sucediéndose albaceas y herederos, ha sido necesario poner orden más en virtud de un principio ordenancista, que predica el orden por el orden mismo, que por un ulterior aprovechamiento de su acervo. En ese sentido cabe representarse el camino de la filosofía como una vuelta atrás, de acuerdo con ese principio de la contabilidad en que el libro debe registrar toda la historia contable hasta el momento en que se produce el último asiento, sin permitirse la menor extrapolación hacia el inmediato futuro: el recorrido de vuelta de aquel camino que la conciencia - paradójicamente - al hacer de ida no se dio cuenta que hacía o al menos no dejó constancia de que lo había hecho [...] (Benet, 1976a: 32).
\end{abstract}

Pero la heterogeneidad de las artes es tal, que el pastiche es de nuestro tiempo; la reconstrucción, el expolio, el construir con elementos prestados es de nuestro tiempo. Ya no existe un estilo de nuestro tiempo [...] (Benet, 1997: 254).

U n ejemplo de la validez de esa «vuelta atrás» filosófica para entender mejor la obra literaria de un autor y para efectuar ese «inventario» intelectual es el análisis de cada importante tesela de su gran mosaico, o «pastiche», intertextual, como es sin duda alguna el caso de la influencia del filósofo Nietzsche (1844-1900), fuente de misterio y de enigma para Epps (1997: 35), en la obra del propio Benet (1927-1993), una de «estilo bifurcado», con «su propia crítica y su propia parodia latente» para Gimferrer (1976: 99). Esta es una idea ratificada por García Pastor cuando comenta que «[...] en el contexto de la novela occidental la obra de Benet es profundamente citativa (uno diría, incluso, «re-citativa»), en el sentido de que remite sin cesar a textos y fórmulas previos que permiten que su obra sea más suya precisamente cuando suena más repetitiva» (1993: 25). De hecho, el propio creador del cronotopo de Región ironizaba metafóricamente, acerca de su amor por la influencia, al afirmar que tenía cierto «temperamento femenino» para ser fecundado por obras con «cierto poder fecundador» (Benet, 1997: 93). Así pues, nadie mejor para dejarle filosófica y 
literariamente «preñado» que el alemán, para muchos el intelectual del siglo XIX más influyente en el XX, sobre todo en tiempos de la postmodernidad.

No es extraño, por tanto, que la presencia de Nietzsche en Benet sea un lugar común para la crítica del narrador madrileño, pero sí que es sorprendente que todavía no haya sido estudiada, analizada ni sintetizada con unos mínimos de atención y de detalle. Hasta el momento, la mayoría de la producción académica sobre este novelista, cuentista, dramaturgo, ensayista e improvisado poeta ha esbozado nada más que ideas dispersas, y muchas veces improvisadas a vuelapluma, acerca de una serie de lecturas nietzscheanas que él realizó a muy temprana edad, anteriores incluso a la de su admirado William Faulkner. Para datar su origen, hay que remontarse a entre 1945 y 1946 (Benet, 1997: 283), año este último en el que conoció a Pío Baroja, cuya tertulia frecuentó, como se puede leer en «Barojiana» (Benet, 1987: 15-51). Ni que decir tiene que el autor vasco estaba también influido por el filósofo, de primera o de segunda mano, como tantos otros creadores en España tal como ha demostrado Sobejano en su estudio Nietzsche en España. Por su parte, Benet ha expresado en estos términos su primer acercamiento al autor de El Anticristo:

Nietzsche es muy importante en la juventud -luego cansa, luego se percibe la grandilocuencia del espasmo nietzschiano- pero de joven eso no se percibe, impacta mucho. Leer a los dieciocho años Humano, demasiado humano o Zaratustra... Por el contrario, en la madurez el Nietzsche que a mí me gusta es el de El origen de la tragedia o La genealogía de la moral. El Nietzsche delirante y loco -agudo muchas veces, de sarcasmo fino-suena a cartón piedra (AA. VV., 1989: 33).

En un artículo de hace ya más de una década, Machín Lucas (2001:25-27) propuso la posibilidad de que en el diseño de los personajes benetianos existieran las huellas nietzscheanas, bastante erosionadas y transformadas por una nueva poética de la prosa, de la dialéctica entre apolíneos y dionisiacos, unificada esta por la figura mítica de Numa y metonimia de los debates entre razón y pasión, entre pensamiento y acción o entre sociedad e individuo. Benet convierte esta díada en pura expresión artística, estética y literaria, de carácter autorreferencial y nada regeneracionista, en contra de lo que pretendía Baroja en su obra César o nada a través de su protagonista César Moncada, fracasado regenerador del procomún. También Machín Lucas mencionó la penetración intertextual de la idea del eterno retorno, del que en la obra benetiana, antro de perdición y de condenación eternas, no se puede extraer nada para el futuro

Gingerich, de manera más supragenérica, filosófica e intuitiva que intertextual, pero de gran profundidad crítica, vinculó a Benet con El nacimiento de la tragedia de Nietzsche (2004: 319). También mostró la noción del papel del otro en la elaboración de la identidad para conectarla entre ambos escritores al ser una constante en la filosofía y en la psicología no solo de este intelectual sino de otros tales como Hegel, Marx, Freud y Lacan (2008a: 84, nota 10). Y en un tercer artículo relacionó de nuevo la obra de Benet con la influencia de El nacimiento de la tragedia y de sus apolíneos y dionisiacos para establecer la dicotomía entre luz y conocimiento y entre oscuridad e ignorancia (2008b: 573), que, a mi entender, en el fondo pueden entroncar con la dialéctica mazdeísta y, por 
derivación, con Así habló Zaratustra, una conexión que también realiza el crítico norteamericano (2008b: 570).

De un modo general, este palimpsesto se inserta en su obra narrativa, compuesta de innumerables «textos corruptos» llenos de marcas y de referencias de otros autores, en tiempos de la postmodernidad. De antemano, es importante ubicar teóricamente el discurso de Benet en el eje que une esas dos coordenadas teóricas: la intertextualidad y la postmodernidad. Compitello dice de la obra de Benet que es el arte de la explotación intertextual y de la «ironic intertextual tension» desde la influencia del antropólogo escocés Frazer y de su obra maestra The Golden Bough (La rama dorada; 1983: 157). El proceso de absorción de un palimpsesto tiene en principio cuatro pasos básicos si se sigue una lectura mimética y superficial: influencia, identificación, incorporación e imitación (Machín Lucas, 2009: 80). Luego, en una lectura semiótica y profunda, se pueden apreciar las nuevas direcciones epistemológicas y de significado que le pretende dar el autor, como pueden ser la idolatría, la repetición de su significado originario, la parodia, la sátira, la reversión, el rechazo o el imposible intento de la anulación, entre muchas otras. Hay que detectar de dónde viene el influjo y unos mínimos de lo que pretendía decir el autor en su época, un hombre por cierto víctima de los códigos de su tiempo y por consiguiente inconsciente de muchas de las cosas que afirmaba, así como determinar cómo penetran las distintas categorías de su discurso en el nuevo texto.

Es la generación y transformación de un nuevo texto, la (re)creación de un nuevo mundo ideológico y estético. En este contexto, la «palabra ajena» nietzscheana penetra, germina y modela el texto de Benet, con el que entra en interacción dialógica según Bakhtin (1981: 279). En sus novelas se cruzan y neutralizan múltiples enunciados tomados de otros textos. En este caso, se van a evaluar los más notorios procedentes de El nacimiento de la tragedia (1872) y de Así habló Zaratustra (1886). La función intertextual se resuelve en un «ideologema» según Kristeva (1974: 15), un elemento de coordenadas históricas y sociales que incide aquí en la España tardo y postfranquista y que absorbe esta filosofía alemana decimonónica. Lo que la misma crítica, deudora de las ideas de Bakhtin y de Noam Chomsky, denomina como «productividad» textual (1974: 15), «no disyunción», «díada asimétrica»o «dualismo concéntrico» (1974: 86) -es decir, la entrada de diferentes estilos simultáneamente en la novela frente a la rígida «díada simétrica» de la épica (1974: 86), de un solo estilo-, se va a apreciar en la novela de Benet al juntar lo filosófico y lo especulativo con lo narrativo, lo épico y lo trágico con lo metaliterario, o lo serio con lo paródico, mezcla que, a su manera, también llevó a cabo el mismo Nietzsche en sus depuradamente escritos tratados.

Para Barthes, el intertexto se puede analizar mediante la división del texto en «lexias» o en unidades mínimas de significado literario en las que se cruzan códigos no jerárquicos, externos o internos a la mente del autor, independientes de la «intentio autoris», tal y como los describe en su obra S/Z: son los hermenéuticos o de enigma, los sémicos o de organización temática, los proairéticos o de acción, los simbólicos o de multivalencia y de reversibilidad de los signos absorbidos, y los culturales o de citas de ciencia o de sabiduría popular (1974: 23-24). En esa maraña de códigos se integrarán las 
influencias nietzscheanas que serán objeto de este estudio. Esta influencia es un caso de melancolía, de nostalgia de un pasado idealizado por Benet, siguiendo a Bloom (1973: 6), que el novelista va a redirigir hacia una crítica de la literatura, del pensamiento, del mundo y de la historia de carácter eminentemente autorreferencial: un mundo literario generado por la realidad pero que, cuando se constituye como tal, se abre y se cierra constantemente sobre sí mismo. El influjo se produce en una obra que no existe «per se», que se fundamenta por las relaciones entre varios textos y contextos que dependen de un acto crítico, de una deliberada mala lectura o de un «clinamen» por parte del autor analizado (Bloom, 1975: 3) para llevar a cabo su propio proyecto artístico, estético e intelectual.

El «hipertexto» o texto en segundo grado, el receptor benetiano, absorbe las más de las veces el «hipotexto» o texto preexistente nietzscheano, usando términos de Genette (1982: 5), en forma de vulgar parodia, la cual para Lara Rallo es central en la literatura del postmodernismo (2007: 138). Esta es una transformación no satírica (Genette, 1982: 26) ya que muchas veces modifica el tema de lo eminentemente filosófico, poético y algo narrativo del teutón a lo primero épico-narrativo, luego lírico y finalmente especulativo y digresivo del español sin modificar las líneas medulares del estilo. A veces el autor de En el estado llega al «pastiche» heroico-burlesco. La mediocridad humana y psicológica de sus antihéroes, castrados psicológicamente por la fatalidad y por la desesperanza, así lo atestigua. No obstante, en otros momentos combina el tema noble de la guerra y de la especulación sobre el tiempo, la memoria, la razón y la pasión con un estilo elevado, depurado, lo que lo inserta en el terreno de la épica y de la tragedia (Genette, 1982: 22 y ss). Por ende, nos hallamos ante el sincretismo típico del «collage» postmoderno, que es para Gonzalo Navajas una «reconciliación del arte elevado y selectivo y el arte bajo y masivo» (1987: 221). Esto, en este caso, se verifica en la combinación entre lo épico, lo trágico, lo científico y lo filosófico con lo más folletinesco y farsante de sus mínimos argumentos. De este modo, las pequeñas y paródicas dosis del arte de masas que hay en la narrativa de Benet son absorbidas por el arte eminentemente elitista de que hace gala este autor (Navajas, 1987: 222).

Tanto él como Nietzsche apuestan por lo que el primero denomina como el «Grand Style»y su «falta de decorum» o estilo único sin caracterizaciones diastráticas o de origen social por personaje. Es el que decayó en España con la llegada del realismo, del naturalismo y del costumbrismo tal y como teoriza Benet en su artículo «La entrada en la taberna» (1965: 111-141). Solo el crítico más avezado y documentado supera el obstáculo de la lectura mimética, denotativa, para llegar a la interpretación semiótica, connotativa, mediante diversos «interpretantes» o signos decodificadores que abren un segundo o varios nuevos significados. Estos explican la relación entre el signo original y gramatical nietzscheano y el derivado y agramatical benetiano, esa mala lectura que propicia ineluctablemente el desarrollo de la mentalidad humana, si partimos de las ideas de Riffaterre y de su hermenéutica estructuralista (1978: 6). Ese paso de la mímesis a la semiosis no solo se aprecia entre ambos autores. Se puede ver incluso en la transformación de Benet de lo referencial de la historia española (preguerra civil, guerra, postguerra...) a lo autorreferencial de la ficción por la ficción, algo característico de su predominante desvinculación de lo histórico, del compromiso y del testimonio, similar a lo que 
caracterizó a la filosofía de Nietzsche hasta casi la última década del siglo XIX. Con todo, en esta actitud también hay un intento de generar una matriz de conocimiento (Minardi, 2012: 180), en este caso uno nuevo más allá de la razón y de la realidad. Una desvinculación que, curiosamente, decreció significativa, aunque no totalmente, al final de su vida con Herrumbrosas lanzas, novela que da más énfasis, aunque no total, al componente histórico de la guerra civil española de 1936 a 1939.

De vuelta a Nietzsche, es asimismo típico el vincularlo con el inicio de cierto postmodernismo cultural a causa de una serie de ideas suyas relacionadas con la ruptura de la confianza en los sistemas de conocimiento y al haber aceptado él el valor de la historia sobre el del progreso el 5 de enero de 1889 en una carta al historiador Jacob Burckhardt, su maestro, colega y amigo, tras un largo desprecio al valor pedagógico de la tradicional. Benet, sin embargo, afirma que Nietzsche creía en la originalidad que procede de la tradición (1965: 132-133), un elemento que deja constancia de su aprecio por el arte de la influencia. Con todo, varios de los rasgos de su filosofía, al pasar a la obra de Benet, lo adscriben al movimiento sociohistórico que se expandió por la segunda mitad del siglo XX hasta nuestros días: la postmodernidad. Recordemos los más básicos de ellos para ver cómo se emparentan con Benet, dimanen directamente de Nietzsche o de sus descendientes y procedan o no de otros autores paralelamente al alemán. La era postmoderna se caracteriza por la reproducción, por el «pastiche» y por el simulacro según Allen siguiendo a autores como Walter Benjamin, Terry Eagleton, Fredric Jameson o Jean Baudrillard, entre otros (2000: 181-188). El afán de Benet de nutrirse de varias fuentes (de Faulkner, de da Cunha, de Frazer, de Bergson, de Jenofonte, de Tácito, de Amiano Marcelino, de La Biblia, de Conrad, de Melville, de Henry James e indirectamente de su hermano William James y de su «Stream of Consciousness» o «corriente de conciencia»...) y de crear un cronotopo imaginario, el de Región, lo evidencian.

Más elementos, que se aprecian en la obra de Nietzsche, se encuentran en la obra benetiana. Por ejemplo, Hassan centra sus estudios en cuestiones de postmodernidad sobre la «indetermanencia» (1987: 91), la combinación de «indeterminación» e «inmanencia» en el espíritu artístico de esa era. También habla de las ideas postmodernas del sujeto vacío o descentrado, del colapso entre ser y devenir, del rechazo de unidad, de la desmitificación de la razón, de la dicotomía entre hecho y ficción y de la «liminalidad» del lenguaje (Hassan, 1987: 48), es decir, de su incapacidad de mostrar lo inexpresable con sus modos convencionales. Renaturalizar un tiempo desnaturalizado por el artificio humano es una de las actitudes características de lo postmoderno de acuerdo con Jameson (1991: 309). Lyotard nos muestra la importancia del sublime, la figuración en arte de lo que es inefable, inexpresable (1979: 78-81). Harvey defiende que es la era en la que la conversión en espacio del tiempo del ser se impone sobre la aniquilación del espacio por el tiempo del devenir (1989: 273). Todo esto se localiza en la obra del narrador de En la penumbra.

En Benet, la noción de incertidumbre, los personajes que se debaten entre la triste realidad y el deseo de plenitud personal y sexual, su falta de futuro a causa del malsano determinismo y de la congelación temporal, su destrucción y fragmentación de la personalidad, sus modos de depurar o de 
alterar por completo la historia, sus experimentos entre el lenguaje pseudocientífico, el pseudofilosófico y el pseudopoético para mostrar las «zonas de sombras» de la razón y de la realidad, la indirección y la ironía, su depuración y naturalización de los palimpsestos en Región y la imposición de los espacios de conciencia, los épicos, trágicos o míticos sobre los puramente geográficos, demuestran su adscripción a este movimiento. Cabe decir que todo ello se produce más en lo formal que en cuestión de contenido, ya que estas ideas ya habían existido antes de la postmodernidad aunque habían sido formuladas de otras maneras y en otros contextos y no necesariamente todas ellas agrupadas al mismo tiempo o durante un mismo movimiento sociocultural.

En el ámbito de la literatura española contemporánea, Herzberger (1997: 10-13) dice que los escritores postmodernistas están en contra de la tradición. Con todo, convendría aclarar que no están tan en contra de este concepto genérico, presente en el fenómeno intertextual, como del concreto de la literatura que les precedió en su país, como puede ser la del «realismo social» de la época franquista. Propone asimismo que la palabra y el mundo se dislocan en esta época, que predominan lo no realista, lo autorreferencial o la ausencia de paradigmas, a pesar de la referencialidad que advierte en su obsesión por la historia y por la historiografía, ejemplos de simulacro postmoderno. Estos conceptos y otros tan manidos por la crítica de la postmodernidad como la desconfianza en los sistemas epistemológicos cerrados; el nihilismo, que advierte el mismo Herzberger (1997: 15); el pesimismo hacia el presente; la mayor importancia de lo irracional sobre lo racional; la desconfianza en el progreso y en el ser; el deseo de poder y de placer y la voluntad de dar más énfasis al estilo que al argumento, van a permear la obra del autor de El aire de un crimen.

En este entramado sociohistórico y metaliterario se inserta la absorción intertextual del filósofo Nietzsche, el cual inyecta a Benet elementos de su obra, de la tradición y de su época que pueden proceder exclusivamente de él o de una red más extensa de intelectuales en la que el alemán se inserta. Para Benet, Nietzsche es un ejemplo de deconstructor cultural, de hombre que revierte los sistemas heredados en busca de otros conocimientos o de novedad (Benet, 1978: 67). Según él, es uno de «aquellos gigantes» o un «genio» de los que ya no existen ya que se «[...] debe considerar si el progreso cultural, en todos los órdenes, no los ha reducido a unas parcelas más modestas [...]», según reza en su artículo «La cultura de la transición» (Benet, 1996a: 201). En «Un ensayo. La deuda de la novela hacia el poema religioso de la antigüedad» (Benet, 1978: 45) lo muestra como el artista que se superó a sí mismo en soledad, siguiendo lo que comentaba de él Thomas Mann. Como veremos, muchas de las influencias no necesariamente son directas, sino que Nietzsche se puede convertir en un punto de fuga para su ramificación en nuevas especulaciones en el presente benetiano. Por consiguiente, daré unos ejemplos simplificados de lo que sin duda es una estructura mayor de transformación de los hipotextos. «Grosso modo», se pueden reducir las constantes polares de la influencia nietzscheana a las siguientes:

1.- La oposición de ambos autores a los sistemas gnoseológicos o de conocimiento logocéntricos, falocéntricos, cerrados y aceptados unánimemente por la sociedad. Desmitifican las nociones 
convencionales del valor de la ciencia, algo curioso en un ingeniero como Benet, y de la verdad como hecho presente y como meta última del acto historiográfico, que desea hacer un análisis completo de la realidad y de abarcarla en su totalidad. Ambos dan primacía a la incertidumbre y desconfían de que el saber haya sido constituido sin errores y de que vaya hacia una meta o verdad última del ser y de la vida. En términos similares opina Michel Foucault sobre los conceptos del origen, de la genealogía de la moral y del saber desde Nietzsche, al partir de la idea de que estos han surgido desde muchos errores y desde malos cálculos, además de no ir hacia un fin teleológico, hacia una causa final (2008: 27, 48 y ss.) que los justifique. De hecho, a propósito de lo que hará Benet en su obra, Ken Benson afirma que Nietzsche desbanca las nociones de verdad como conocimiento unívoco y estable (2004: 126). Además, derivado de esto, ambos defienden el fragmentarismo frente a la unidad.

Ejemplos palmarios de Nietzsche se pueden encontrar claramente en Así habló Zaratustra (2009b: 173, 174, 176 y 182), como por ejemplo: «Y en esto consiste mi imaginación y aspiración, en imaginar y reunir en una unidad lo que es fragmentario y enigma y espantoso azar» (2009b: 174). En cuanto a Benet, David K. Herzberger dice que este da valor de verdad a hechos con un valor histórico tradicional, a pesar de que Nietzsche declaró la muerte del hecho y el imperio de la interpretación. No obstante, afirma que no suscribe del todo la influencia nietzscheana (1995: 91). Esto es discutible a la luz de la autorreferencialidad que prepondera en la obra de Benet y de su desconexión con la noción de verdad oficial, opuesta a la verdad ilusoria que trata de crear y que se atrevió a insinuar Ricardo Gullón en sus regionatos laberintos del espacio, del tiempo, del personaje, del discurso y del lector (181, 184, 186, 188 y 193) a pesar de seguir manteniendo que Región tiene como referente primario España sobre los intertextos anteriormente aludidos. Aparte de lo ficcional de la Guerra Civil, incluso dentro de la diégesis quedan elementos inconexos y sin lógica, adulterados por la pasión, la memoria y el tiempo que arrasa lo vivido, y se aprecia una evidente contradicción entre el mapa o cartografía de Herrumbrosas lanzas y las referencias geográficas y topográficas del texto como explica Margenot III en su artículo «Cartography in the Fiction of Juan Benet». O, en la misma obra benetiana y según Epicteto Díaz Navarro, no hay una verdad histórica definitiva acerca de la guerra (72). El testimonio, en conclusión, está supeditado a una literatura que por momentos se convierte en pura poesía, como aprecia Gonzalo Sobejano acerca de Saúl ante Samuel (174).

Véanse los dos siguientes fragmentos como botón de muestra. El primero ha sido extraído de un artículo titulado «Esferodoxia» en el que Benet sitúa a Nietzsche entre los grandes intelectuales universales que cuestionan, si no es que dinamitan, todo intento de reducir la realidad a leyes completamente inamovibles y perfectas que la expliquen. En él, lo opone, junto a Empédocles, a Montaigne y a Novalis, a los «esferodoxos» o defensores del sistema científico cerrado. Según él son

[...] unos malditos fácilmente desacreditables; por su incapacidad para crear un sistema cuya acción se puede comparar en último término a la perforación de un tejido que tras la herida se regenera y reconstruye sin siquiera dejar cicatriz. Es posible que lo que más ofenda de esos hombres no sea tanto la fugaz herida que producen sino la más perdurable demostración de la vulnerabilidad del envoltorio. Esa esfera, ese globo, ese tejido explota el mejor día. La ciencia esferodoxa tanto más se afana [...] en aportar datos concordantes con la ley universal, tanto más está creando la mezcla explosiva que amenaza la envoltura (1983a: 111). 
Filosofía, intertextualidad y postmodernismo: la influencia de Friedrich Nietzsche en la obra...

El segundo procede de su artículo «Ingeniería e intimidad», en el que dice del mundo del arte lo siguiente:

Y Nietzsche vendrá a decir, como una advertencia a tantos y tan imprudentes experimentadores modernos en el campo del arte, que el verdadero innovador no es aquel que rompe con las limitaciones históricas impuestas por un canon artístico cualquiera, sino en mucha mayor medida aquel otro que impone una limitación más a la obra de arte tópica con que se enfrenta (1983b: 165).

Por añadidura, hay este otro de Volverás a Región. Se puede apreciar con claridad meridiana cómo su intertexto o acicate intelectual puede ser el alemán (las cursivas de aquí en adelante son mías y los solecismos anotados con un «sic» son de Benet):

[...] sumido en esa repentina explosión de polvo añejo y fétido en que al atardecer -al conjuro de sus palabras, esos instantes anteriores a la lluvia tan propicios al fenómeno fotoquímico-, última coloración de un fluido inestable, pierde su estructura diurna para descomponerse en mil fragmentos de un tiempo caótico y gaseoso, en cada uno de los cuales está alojada (sic) -como el germen en el grano de polen-palabras, trozos de memoria, indicios de recuerdos abortados y falsos y engañosos ecos que la noche y el día borrarán al reestablecer el equilibrio de las horas. [...] la memoria no guarda lo que pasó, [...] la voluntad desconoce lo que vendrá [...] (1967: 121).

2.- La defensa de lo irracional como nueva línea epistemológica y como expansión de los límites del racionalismo imperante, más allá de nuestras imperfectas fronteras mentales. Se hace prevalecer lo indeterminado, la incertidumbre, lo inconsciente sobre lo consciente, lo ensoñado y alucinado sobre la vigilia o lo espiritual sobre lo somático. Se muestran en contra de los dogmas de fe y de las verdades absolutas que son similares a las mentiras. Unas son aceptadas y otras no por una cuestión de imposiciones determinadas por los vaivenes, por las victorias y por las derrotas en las luchas de poder. Todo es tamizado por un intelecto mermado y por una memoria selectiva, falseadora e idealizadora.

Agustín Izquierdo cree que para Nietzsche al conocimiento no se llega a través de la lógica o de lo racional, sino de creencias y de prejuicios, algo relacionado con las condiciones fisiológicas de la persona (2000: 67). Hay ejemplos de Nietzsche acerca de la irrupción de lo irracional en el mundo lógico, un desbordamiento epistemológico que va más allá de los límites y de la mesura típicas del racionalismo, en la obra El nacimiento de la tragedia cuando habla de las limitaciones de lo científico: «[...] el problema de la ciencia carece de solución en el terreno de la ciencia. [...] contemplar la ciencia desde la óptica del artista, mas el arte desde la óptica de la vida ...» (2009a: 36-37). Así lo deja cuando explica la naturaleza de las fiestas dionisiacas, básicas en su concepto de tragedia, en un apolíneo «mundo erigido sobre la apariencia y la mesura»:«[...] la desmesura toda de la naturaleza materializándose en un intenso grito desgarrador» (2009a: 71). En pocas palabras, el mundo se expresa más a través de un alarido terrorífico que de la lógica al uso. Y también se puede detectar este tema en Así habló Zaratustra: «Aquí se me abren de repente todas las palabras del ser [...]» (2009b: 225). Es la polisemia plurisignificante y pluriperspectivista de lo que está más allá de la razón cartesiana convencional y del logocentrismo al uso. 
Benet deja bastante claro que esta influencia nietzscheana le ha germinado. Desde su magisterio intelectual, cree que la razón es simplemente un convenio social, un pacto para equilibrar fuerzas de poder, lleno de errores de base, de agujeros y de lagunas que a duras penas pueden explicar, rellenar o completar el mundo que se sustenta sobre el logos irracional, que es expresión de lo multiforme de la creación y de la vida. Así lo expresa esta curiosa combinación de científico y de literato: «[...] la racionalidad, como la moral cuyas bases denunciara el Nietzsche de Aurora, es poco más que lo compartido y comienza a perder toda entidad en cuanto se le extrae su núcleo social [...]» (1976a: 94) o también «[e]l arte, decía Nietzsche, no consiste en ampliar sus límites sino en buscar cada vez más límites» (1997: 128). Otros ejemplos extraídos de su interesante producción ensayística son estos:

[...] lo irracional se convierte en algo sinónimo a lo intelectualmente inconveniente, nocivo o enfermizo y no podía ser de otra manera siempre que se convenga que el carácter de la salud intelectual sólo socialmente puede ser definido. [...]. No puedo perder de vista que la racionalidad, como la moral cuyas bases denunciara el Nietzsche de «Aurora», es poco más que lo compartido y comienza a perder toda entidad en cuanto se le extrae su núcleo social, esa especie de hueso elaborado para su preservación y rodeado de la carne donde la filosofía hundirá el diente para extraer su bocado eurístico (sic) (1976a: 94-95);

[...] por uno de tantos sarcasmos suyos, la historia parece haber reservado el veredicto de irracionales a aquellos que tomaron demasiado al pie de la letra y hasta sus últimas consecuencias los métodos racionales (1976a: 95-96).

Y esto no se acaba aquí. Hay otros numerosos ejemplos de esta transmisión intertextual en Benet ya que este es un tema básico para él, no solo en determinadas intrusiones palimpsésticas de ciertos motivos sino también en la macroestructura narrativa e ideológica. Es la presencia del «otro yo irracional y activo» de que habla Antonia María Molina Ortega acerca de su obra (2007: 129). Es el espacio de las «zonas de sombras», a las que llega el hombre deliberada o accidentalmente en su búsqueda del saber más completo y en su paso de la palabra al símbolo. Allá los modos de conocimiento convencionales se podrían detener: «[...] es posible que, en un momento determinado, una combinación casi fortuita de palabras o ideas le lleve a una zona de sombra, no sólo donde el conocimiento no ha entrado todavía, sino ante el cual se detiene y suspende toda actividad» (1976b: $50)$.

En el terreno de la literatura, como se aprecia en el artículo «Onda y corpúsculo en el Quijote», Benet deja muy clara su declaración de intenciones acerca de las relaciones entre literatura e irracionalismo: «[...] a menudo la obra literaria propia se produce como un imperfecto -pero logradointento de desvanecer el misterio que la literatura opone al conocimiento» (1981: 78). Si entramos con más precisión en sus géneros, se hace evidente que tiene opiniones similares sobre la epistemología de la poesía frente a la fe y a la confianza en las reglas del pensamiento de la ciencia. El de lo poético es el territorio en donde se albergan la duda y la inseguridad frente al saber firme: «[...] la lectura de la poesía tiende a inducir en quien la practica una cierta inseguridad acerca de su mente y a la larga logra constituir sobre la duda un cimiento permanente de ella» (1976b: 60). De hecho, pone al poeta romántico John Keats como ejemplo de la búsqueda de una «capacidad negativa» que nos sostenga 
«sobre la incertidumbre, las dudas y los misterios sin una irritable apoyatura en los hechos o en la razón» (1976b: 88).

Pero además considera que esas pueden ser características también de la novelística, sobre todo de la poética que él mismo practicó, similares a la imposibilidad de reducir la ontología del ser humano: «Lo sustantivo de ella es lo que queda fuera de la novelística, de la misma manera que lo sustantivo de un individuo es aquello que ninguna ciencia puede decir de él [...]» (1976b: 76). También expresa la necesidad de practicar una historia poética o irracional esotérica más allá de todo intento de restituir esencialmente la verdad histórica exotérica. En su artículo «Sobre el carácter tétrico de la Historia» nos dice lo siguiente al respecto sobre la enseñanza de la historia: «Que no se vacile en mezclar en un conjunto de disciplinas racionales, todo el elemento irracional y pasional que atesora la historia» (1970a: 177).

En su novelística, innumerables ejemplos de esta temática se pueden hallar ya que es un tema básico en el «condensado ideológico» benetiano (Minardi, 2010: 198). Algunos de los más interesantes se localizan en Un viaje de invierno, sobre todo en las anotaciones marginales o «ladillos» que muy lúcidamente explicó Félix de Azúa en su artículo «El texto invisible...». Para este, esas anotaciones interactuaban o dialogaban con el texto principal o «texto de caja» y abrían una tercera lectura por proceso de tesis, antítesis y síntesis que bien pudiera ser la más cercana a la irracional. He aquí tres claros ejemplos de los que se pueden localizar en esa novela regionata:

Tanto si se conforma con los cambios, tanto si se afana en la búsqueda de las causas que los producen, la historia pretende la satisfacción de un afán de saber que respecto al pasado puede pasar por alto muchas motivaciones por el simple hecho de que no dejan huella (1972: 108); [c]on frecuencia se han confundido razón de ser y causalidad, introduciendo el equívoco entre reflexión y razón (1972: 118); y [d]urante todo el viaje la razón ha presumido de saber a dónde iba. Ha prometido mucho y bueno y apenas ha permitido a la conciencia quedarse en un lugar de su antojo. Pero cuanto más se acerca a la meta más recapacita y más necesidad tiene de exagerar el engaño (1972: 120).

En puridad, lo irracional para Benet se convierte en la llegada a aquellos límites que demuestran las insuficiencias cognoscitivas de la imperfecta razón. Es una ampliación epistemológica del espectro de lo racional para alcanzar un cierto conocimiento del que se nos ha privado a causa de las limitaciones de nuestra mente y de nuestros sentidos. En estos términos se expresa:

El hecho de que todo conocimiento puede ampliarse, que la última realidad siempre escapará a la razón, que la ciencia es un estadio intermedio, una marcha que no tiene meta y que, en último término, la realidad aprendida es una realidad a medias y por tanto tan irreal como real, apenas tiene otra resonancia que para cierta mítica -entre literaria y metafísica- incapaz de salir de la contemplación de ese abismo (1976a: 105-106).

3.- La presencia del nihilismo. La muerte de Dios como concepto moral y su sustitución por una veneración a la vida y a las pasiones desbordadas. Gianni Vattimo alude a la idea nietzscheana postmoderna de que Dios muere porque la razón asume que no lo puede alcanzar (1988: 24). En su ausencia, se centran en lo egocéntrico, en lo inconsciente, en lo paranormal y en lo ficticio. Se devalúan 
los grandes tabúes culturales que surgían de ese concepto y todo lo que se creía intocable como es el caso del cristianismo. Se imponen lo decadente, el pesimismo, lo feo, lo violento, lo extraño, el displacer y el placer morboso o más primario. Frente a la miseria presente, se produce una compresión espacio-temporal para tratar de escapar de este «locus eremus» y se entra en los reinos de lo intelectual y de lo esotérico. Por esta desconfianza, rechazan el progreso y miran hacia la historia (como hacía mayoritariamente el Nietzsche previo a 1889) porque en ella se puede fantasear con un pasado idealizado que nunca existió y que sin embargo se deseó.

En El nacimiento de la tragedia se confía más en la «[...] sobreabundancia de vida, dolor y placer [...]», la cual reside en el espíritu trágico, que en la promesa de una eternidad (2009a: 161-162). Esto deriva en un pesimismo con posibilidades heurísticas y de optimización orgánica, social e intelectual:

¿Es el pesimismo necesariamente un signo de decadencia, de degeneración, de fracaso, de instintos cansados y debilitados [...]? ¿Existe un pesimismo propio de la fortaleza? ¿Una predisposición intelectual a la dureza, al horror, al mal, al hecho enigmático de existir, que hunde sus raíces en una salud desbordante, en una existencia plena? ¿Existe tal vez un sufrimiento derivado de ese mismo exceso de plenitud? (2009a: $34)$.

Es el «[...] trasfondo ético de la tragedia pesimista: su justificación del mal del hombre [...]» (2009a: 102). Esto nos lleva al deseo de lo repelente, de la degeneración, del declive, como sinónimo de vida (2009a: 39). Asimismo, es famosa la frase de Nietzsche «Dios ha muerto» en Así habló Zaratustra (2009b: 19), un óbito en el que se insiste a lo largo de esta obra (2009b: 112, 306-308), si bien la figura de Cristo pudiera tener la grandeza de un espíritu entre lo apolíneo y lo dionisiaco, ideas cruciales para este filósofo en el ámbito de la tragedia.

Por su parte, Benet ya insinuaba en su horma crítica que había aflorado en España un «exagerado» neo-nietzscheanismo de carácter nihilista tras la muerte de Franco (1997: 139), aunque ya se evidencia en su obra anteriormente puesto que Volverás a Región se había publicado ya en 1967 tras más de una década de gestación. Acerca del mismo Nietzsche afirmaba que «[...] en asuntos de decadencia era el más sabio de Europa» (1965: 130) y lo proponía como experto en esas materias y en otras de desencanto (1987: 26). También se puede apreciar su desprecio al cristianismo como teología y como ética de una Iglesia castrante tanto en lo moral como en lo cultural por lo que se evidencia en su artículo «Roma, $360 \mathrm{AD}$ » al hablar de manera inequívoca del «[...] papel que, a partir del 380, Teodosio asignó a la doctrina cristiana, para grave perjuicio del mundo civilizado.» (1982: 32).

En su obra novelística, los personajes parecen haber abandonado su ilusión por la vida terrenal tanto como por la eterna, y se han resignado a la «epojé», a la suspensión del juicio racional, a la apatía, a la abulia y a cierta ataraxia y solipsismo al sentirse dominados por un destino trágico prefigurado, determinado. Un existencialismo «sui generis» que detecta David K. Herzberger cuando menciona como clave la idea nietzscheana de que «nuestra existencia es un tiempo imperfecto nunca completado» (1999: 144-145). Dios ha desaparecido y en muchas de sus obras a sus entes de ficción 
les parecen gobernar unas fuerzas inmemoriales que les determinan, como son las invisibles del bosque de Mantua en sus obras regionatas. No obstante, se defiende el ejemplo de Cristo como líder espiritual pero se rechaza el valor del cristianismo como doctrina moral y religiosa que anula las potencialidades y los instintos creadores humanos, como se puede apreciar en Saúl ante Samuel en boca de la pitonisa, la abuela oracular:

Así que a los amantes de Cristo nada nos importa que acabéis con los cristianos -tal vez en secreto nos regocija-, tan dura es la obligación de compartir su amor, incluso con los que lo merecen-porque $a$ él no nos lo podréis quitar y tal vez a solas y en exclusiva su amor resulte más agradable. Lo malo es la doctrina, la palabra, incluso la fe. Las promesas. No son más que vehículos para llegar a él pero una vez en él, todo lo demás ¿qué más da? (1980: 205).

En Volverás a Región el Doctor Sebastián hace gala de una sarcástica sabiduría sofística al defender la capacidad nutricia de lo pésimo cuando le dice a Marré Gamallo lo siguiente sobre el valor de las lágrimas y de la melancolía en el aciago mundo en el que han nacido: «Los que vivimos en esta tierra necesitamos un plato más fuerte, una diversión más brutal. [...] Me refiero al fatalismo, un plato de más sustancia» (1967: 136). En la misma novela, el cústode de ese destino predeterminado, el mítico Numa, mantiene con un certero disparo el «ordo tremoris» y el estatismo temporal al eliminar a todos aquellos que tratan de abandonar la comarca por segunda vez. Vende como positiva a un lector ideal, al que asimila como participante en la tragedia regionata, con cierto cinismo y tono autoritario, la desgracia de los infaustos regionatos y de todos aquellos que traten de hollar su recinto sagrado:

¿Qué dices tú de la condición? ¿Y del futuro? ¿Que carecéis del futuro? Reflexionad: un futuro sólo se abre a las amenazas, todo lo demás son habladurías. Volved a casa; no os llaméis cobardes ni ruines, no ha lugar a eso porque en vuestra ruindad hay escondida toda una ciencia del destino (1967: 266-267).

Y para finalizar, cabe analizar los ladridos de un perro (1967: 331), vinculados a Nietzsche por un narrador paratextual, en una cita y en una nota de a pie de página. Tradicionalmente ellos simbolizan la llegada de la muerte y son un ejemplo de «recurrencias» benetianas según Víctor García de la Concha en su introducción a Volverás a Región (1967: LXXVII-LXXVIII). Una muerte que es el único resultado esperable de ese nihilismo.

4.- La presencia del espíritu de lo trágico como fenómeno estético paralelo a la vida, falto de proyecto o de imperativo ético y moral, y como forma ensoñada de conocimiento del caos del mundo, de lo humano y de la existencia. Es un tipo de influencia que determina la autorreferencialidad de la obra de Benet y el peso de un destino de carácter incivil en ella. Nietzsche dice esto en El nacimiento de la tragedia:

Con este libro, mi instinto problemático arremetió, pues, contra la moral, inventando, en cuanto instinto abogado de la vida, una concepción y una valoración diametralmente antitéticas de la vida, puramente artísticas, anticristianas. (2009a: 43); [P]ara levantar este coro, el hombre griego ha construido el andamio flotante de un estado de naturaleza ficticio, colocando, sobre éste, a seres naturales no menos ficticios. La tragedia ha terminado erigiéndose sobre estos cimientos; esta es la razón por la que desde sus inicios se ha librado de la fastidiosa obligación de retratar fielmente la realidad (2009a: 87); 
[...] [E]l elemento idiosincrásico de lo trágico radica en la lucha del héroe con el destino, en la victoria final del orden moral o en la catarsis afectiva que suscita [...] (2009a: 171).

La esencia de lo trágico y los discursos del coro se yerguen en expresión simbólica de la relación entre la cosa en sí y la apariencia (2009a: 91) deslindada de categorías morales. Hay otros ejemplos de la inmoralidad trágica, anticristiana por esencia, en Así habló Zaratustra. Este dijo a sus discípulos: «Los buenos y justos me llaman el destructor de la moral: mi historia es inmoral.» (2009b: 86). Y la vida le dice a Zaratustra: «Los dos somos incapaces tanto de hacer el bien como de hacer el mal. Más allá del bien y del mal hemos encontrado nuestra isla y nuestro verde valle [...]» (2009b: 272).

La obra regionata se mueve en un espectro completamente predestinado, pesimista e inmoral. Eduardo Chamorro habla de una «[...] tragedia sin resolución posible, únicamente abocada a la conciencia de la desventura como estricto espacio en el que desarrollarse [...]» (1976: 120). David K. Herzberger, al estudiar Volverás a Región, cree que historia y tragedia van unidas en su interior (1999: 143). Saúl ante Samuel es denominada por John B. Margenot III como una «tragedia bélica familiar» (1991: 40). Las inestabilidades de la memoria y de la historia son iguales a las de la tragedia y, por extensión, similares a las ideas de Nietzsche según Ken Benson (2004: 67-68). Estas conexiones incrementan el elemento metadiscursivo y metafictivo de las obras, sin compromisos históricos ni implicación emocional excesiva por parte del autor ni del lector.

Hay bastantes ejemplos en el tejido de la obra de Benet que inciden en el tema de su autorreferencialidad y de su antirrealismo propiciado por el carácter de infausto trágico que infunde a sus novelas. Su interés en este tema se aprecia desde sus ideas acerca de la tragedia en la figura de William Shakespeare en su artículo «Cordelia Khan» (1970a: 142-167) y en «Sobre el carácter tétrico de la Historia»:

Muy raras veces en la tragedia triunfa el mal; en general en la tragedia deben sucumbir todos los principios activos, tanto los del bien como los del mal, para que tras la consumación de la misma el nuevo orden recaiga sobre unas manos no teñidas por la sangre de la lucha: pero incluso ese consolador final apenas es capaz de disipar el horror que produce el antagonismo de los principios (1970a: 191).

La tragedia está encaminada de buen principio hacia un inevitable final, atrapados sus personajes por un inapelable destino. Para eso, para analizarla se necesitaría una moviola (1997: 72), idea procedente del artículo de Benet titulado «La moviola de Eurípides», en el que dice que «[e]n comparación con el drama, la tragedia despliega un argumento al revés, regresivo y remontante, pues el fin trágico está de tal manera impuesto que ningún acontecimiento puede cancelarlo, antes bien con su determinación no hará sino precipitarlo [...]» (1981: 17). Finalmente, para el escritor español la tragedia es como la comedia al ser el holocausto final como un «Happy End» ya que, dada la desgracia que vive el protagonista, «[...] la prolongación de la vida del héroe sería mucho más espantosa que su muerte $[\ldots] \gg(1978: 86-88)$. 
Filosofía, intertextualidad y postmodernismo: la influencia de Friedrich Nietzsche en la obra...

En sus novelas se ve ese tono trágico en su falta de realismo, en la primacía de las apariencias, en su «falta de decorum» y en la lucha baldía del hombre frente a su fatídico destino, todos ellos elementos típicos de las tragedias. Para entenderlas sería bueno aplicar la idea de la moviola retroactiva, es decir, tener en cuenta desde el inicio de su lectura que tanto el final de la novela como su argumento carecen de interés ya que se sabe cómo van a acabar de antemano: negativamente, con la muerte o el castigo eterno del protagonista. Por tanto, hay que ir hacia atrás para ver cómo se desencadenan los hechos, cómo se desarrolla la temática y cómo se elabora su alto estilo. Dos lecturas se superponen a la inversa, casi como una especie de metalepsis.

Yendo más directamente a algún ejemplo que ilustre la entrada de la tragedia en su obra, véase cómo compara Benet la historia de los cainitas hermanos Beltrán de Rodas con la estructura teatral de una tragedia en Saúl ante Samuel:

Ambos eran cautos, deseosos de guardar las distancias y apariencias [...] ambos encarnaban a la perfección los diferentes y antagonistas papeles que les habían correspondido en el reparto de la tragedia para cuyo primer acto se acababa de levantar el telón... [...] acompañándose de recursos tónicos y cierta grandilocuencia, inducir en el auditorio el sentimiento de que todo se ha de degradar [...]. Ciertamente, con qué triviales conocimientos y con qué infantil resolución se entrega el héroe al curso de la tragedia-tanto más terrible cuanto mayor es la inocencia inicial- que con frecuencia sólo sabe ver como una artificiosa mascarada en la que se aviene a colaborar en la seguridad de que todo quedará en nada (1980: 156).

El caso más claro de irrupción de la estructura y de la temática trágicas está en la fórmula que combina lo novelístico y lo teatral de La otra casa de Mazón.

YOSEN: El mundo que vivimos no es real [...]. No me gusta ser racional ni amo lo que quiero. No comprendo el orden ni las leyes [...] (1973: 219);

CRISTINO MAZÓN: Cuando se posee-como yo- una moral firme, la edad no afecta. Casi se suprime la edad, fíjate bien. Porque cuando se tiene una moral tan rígida como la mía, yo creo que no se puede mover un dedo. No se puede hacer nada, nada: todo está mal (1973: 50);

CRISTINO MAZÓN: Confianza en... bien mirado, confianza en nada, una gran cosa. Así, pues, pase lo que pase todo será para bien. O para mal. Da igual. Y te digo que da igual porque una moral rígida como la mía no permite esas ridículas distinciones entre lo bueno y lo malo. Quede eso para las personas ambiciosas. Una moral rígida y una confianza absoluta en que, en esencia, no ocurrirá nunca nada (1973: 51-52);

EL REY: [...] El mal, el bien, el eterno femenino.

CRISTINO MAZÓN: Yo nunca he comprendido demasiado bien esa diferencia. Me parece que la distinción entre bien y mal sólo tiene sentido en el ambiente familiar. Fuera de la familia todo es igual, ni las cosas gozan de carácter ni vale la pena establecer diferencias. En la familia, en cambio, sí (1973: 168169).

5.- La dialéctica entre personajes apolíneos, serenos, luminosos, armónicos, bellos, superficiales, pasionales o espirituales, y personajes dionisiacos, desequilibrados, desmesurados, no armónicos, feos, profundos, de acción o sensuales. Hayden White cree que Apolo simboliza lo trágico que preserva la belleza en lo transitorio (1973: 340 y ss.). Apolo es así pues para Dionisio la rigidez, la represión, la opresión. Dionisio es para Apolo lo transitorio en la belleza trágica, lo cómico que destruye, la regresión a la barbarie. Son dos tipos de personajes, de creaciones y de seres, pero también las dos 
caras de un mismo ser, de un mismo ego, que se transforma constantemente dentro de una realidad que fluctúa en el espacio de unas esencias apriorísticas.

Son las facultades del hombre en la tragedia y en la ficción. Son dos actitudes filosóficas, espirituales y estéticas para Nietzsche. Aquí hay algunos ejemplos de Nietzsche en El nacimiento de la tragedia:

[...] la evolución del arte está ligada a la duplicidad de lo apolíneo y de lo dionisiaco; del mismo modo que la reproducción de la vida depende de la dualidad de los sexos, coexistentes en medio de una lucha perpetua sólo interrumpida ocasionalmente por treguas de reconciliación (2009a: 50).

Apolo es el arte plástico y Dionisio es el no plástico de la música y juntos engendran la obra artística de la tragedia (2009a: 51). El grito de júbilo de Dionisio rompe los límites de la individuación, se convierte en acción y en liderazgo colectivo, y Apolo transfigura el «principium individuationis» para redimirse individualmente en la apariencia (2009a: 134-135):

Provisto de la ingente fuerza de la imagen, del concepto, de la doctrina ética y del impulso compasivo, lo apolíneo tira con fuerza del hombre hacia arriba para que no caiga en su autodestrucción orgiástica, disimulando la universalidad del proceso dionisiaco e induciéndolo al delirio de ver una imagen aislada del mundo [...] (2009a: 167).

El mito trágico, por ende, lleva al mundo de la apariencia a negarse a sí mismo para entrar en la auténtica realidad (2009a: 170), la estética.

Benet hace un diseño narrativo, poético, filosófico, psicoestético y de personalidad rígido. El intertexto nietzscheano se va a desviar hacia dos tendencias inactivas, incapaces y estériles en la obra de Benet. Este binomio de actitudes está condenado a la ruina, es propio de seres débiles y apáticos, caracterizados entre lo personal y lo no personal, como puros espectros ideológicos, ahuesados, sin crecimiento interno, flotando en la «durée» o tiempo de la conciencia bergsoniano para Herzberger (1976: 59, 69). En un principio parecen aludir a la dualidad subyacente entre razón y espíritu, que caracterizó Ken Benson, desde una óptica estructuralista y como clave de la obra benetiana en su estudio titulado Razón y espíritu... Las fuerzas deterministas del bosque de Mantua, procedentes de The Golden Bough de Frazer, son las que los castran y Numa el que los engarza en su seno, a la par que los controla y castiga cuando se exceden en sus pasiones. En la novela de Benet, todos acaban siendo asimilados cerca de los claroscuros del radio de acción de los apolíneos, el más inactivo, el menos somático, por su frustración y por su fracaso para rebelarse contra los dictados de esas fuerzas míticas.

Pero en ese espacio no se convierten en luz, sino en un modo de pensamiento lleno de oscuridad, de tristeza y de resignación. Son la luz y las tinieblas, el sueño y la embriaguez, la estampa y el argumento (1965: 190-192), estas últimas categorías entendidas como «corpúsculo y onda» en «Onda y corpúsculo en el Quijote» (1981: 85, 88), determinadas por la fatalidad. Aunque acertadamente Herzberger dice que no hay noción maniquea entre el bien y el mal en la obra benetiana (1984: 106), 
se puede apreciar otro tipo de maniqueísmo. Es el que inspira esta idea, que viene filtrado por Nietzsche desde la dialéctica mazdeísta-zoroástrica-parsista. Es la unión del oxímoron, la lucha de contrarios en la literatura y en el mito frente a la búsqueda de certeza del mundo contemporáneo para Mariano López López (1992: 28).

Hay una galería de ejemplos en Benet que ratifican esta ascendencia intertextual:

[...] que una mente clarividente lo ha de ser en la medida en que será capaz de contender con una mente embriagada y que sólo en la pugna entre las dos-siempre incierta y jamás desembocando en la victoria de uno u otro contendiente- se puede contemplar la actividad del espíritu (1976b: 89).

Vicente Cabrera en su libro Juan Benet ve esta dualidad subyacente de esta manera, señalando su fracaso y absorción final por una de las categorías: «Conviction and despair. [...] Fear is common to both» (1983: 86). El miedo está más cercano a la apolínea, la menos activa, la más resignada a la contemplación por su fracaso ante la acción regenerativa. John B. Margenot III, al discutir sobre la importancia de la casa claustro en su obra, de lo exterior y de lo interior, del aislamiento físico y temporal de los personajes, los divide entre enclaustradores y enclaustrados (1991: 115).

En las novelas de Benet se ve esta dialéctica desplazada o absorbida por lo apolíneo, degradado por la noluntad, por la inmovilidad y por la frustración en la alienación. Por ejemplo, se aprecia en Volverás a Región, tanto en la pseudodionisiaca Marré, que se lamenta de su falta de plenitud sexual, como en el pseudoapolíneo Doctor Sebastián, resignado y amargado por sus irresoluciones vitales en el amor y en la guerra, personaje que controla al hombre niño semienloquecido, su propio metafórico trasunto, para que no se desborde, aunque al final de la narración le haya de eliminar. Sus dos soliloquios, que no diálogo ya que a duras penas estos dos personajes se escuchan o interactúan, lo evidencian en su aislamiento individual frente a la sociedad, a la historia y al tiempo cronológico. La coacción se impone a la libertad, la pasión a la razón y el vacío temporal al tiempo cronológico y ontológico. Hay unos ejemplos más de esta dialéctica que en su seno lleva el espíritu del oxímoron, la cual alberga la incertidumbre y el enigma que tanto le gustaron a Benet.

Por ejemplo, el solitario y celoso Cayetano, que obsesivamente repara relojes en su intimidad, frente a Leo y a Carlos que viajan en busca de su plenitud amatoria en Una meditación, todos los cuales serán destruidos por el arrasamiento telúrico de la zona al final de la novela; o Cristino y su moral no activa frente a un Yosen desesperanzado, ambos carentes de futuro en La otra casa de Mazón; o la inactiva Demetria y sus ritos de fertilidad - como los dionisiacos- que motivan la fiesta por la vuelta de Coré en Un viaje de invierno, obra en la que la estructura binaria entre Amat y su lectura inversa Mata es equivalente a la que hay entre el «eros» y el «tanatos»; o la tía que es puro pasado fracasado y la sobrina que es puro futuro frustrado en En la penumbra; o Emilio, el soldado, que se contrapone a la reflexión en forma de rememoración metaliteraria del primo Simón y a la que se constituye en visión esotérico-profética de la abuela sibila en Saúl ante Samuel, obra que por cierto engloba los mitos bíblicos del Rey coronado por el profeta que lo evalúa y juzga y de Caín y Abel, visible este último en 
la rivalidad entre los hermanos Beltrán de Rodas, similar a la que hubo entre republicanos y nacionales durante la Guerra Civil española.

6.- El eterno retorno. El tiempo cíclico que en el caso de Nietzsche pretende volver al pasado para aspirar a superar un presente decadente y a llegar a un futuro mejor de la mano del superhombre, aunque desconfíe de esa posibilidad algunas veces. En Así habló Zaratustra este mismo personaje nos invita a recorrer el camino no solo inmanente sino cíclico que va hacia uno mismo (2009b: 80) y a arder en nuestras propias llamas para renovarnos (2009b: 82), para acabar afirmando con un claro nihilismo en el presente:

¡Todo está vacío, todo es idéntico, todo fue! (2009b: 167);

Todo se va, todo regresa; eternamente gira la rueda del ser. [...] En cada instante comienza el ser [...]. Curvo es el sendero de la eternidad (2009b: 261);

[...] todas las cosas retornan eternamente y nosotros mismos con ellas, [...] nosotros ya hemos existido infinitas veces, y todas las cosas con nosotros (2009b: 265);

«En el fondo todo permanece inmóvil», -ésta es una auténtica enseñanza invernal, una buena cosa para tiempos estériles, un buen consuelo para los que hibernan y para los trashogueros (2009b: 243);

[...] el que ha terminado por conocer los viejos orígenes, he aquí que al final buscará fuentes del futuro y nuevos orígenes (2009b: 253);

[...] que todo sea eternamente igual a sí mismo (2009b: 375-376).

En el mismo libro da su noción del tiempo cíclico y del pesimismo que expresa a veces acerca de lo que se puede repetir:

Yo soy de hoy y de ayer [...] pero hay algo en mí que es de mañana y de pasado mañana y del futuro (2009b: 161);

En verdad, ¡también para el mal hay un futuro! [...] ¡A cuántas cosas se las llama ahora la peor de las maldades, y no tienen más que doce pies de ancho y tres meses de duración! Pero en el futuro vendrán al mundo dragones mayores (2009b: 179).

Hay bastantes ejemplos que emanan de estas nociones en Benet. En su obra lo cíclico es lugar de condenación inmemorial en la fatalidad y sin perspectivas de ir hacia un futuro mejor. Es el famoso motivo de la vuelta a Región. Así se pretende recuperar a través de la llegada física, de la conciencia del dolor y de la memoria una identidad y un pasado impostados para intentar depurarse e ir a un futuro sin esperanza en lo nuevo, sin desarrollo ni evolución. De hecho, Santos Alonso habla de una estructura circular en En el estado y en Saúl ante Samuel (1983: 69), que es extensible a la estructura básica de otras de sus novelas como Un viaje de invierno o, por descontado, Volverás a Región. Patricia Martínez García entiende esta última novela como un laberinto de historia cíclica (1996: 409) y Monique de Lope también menciona esta idea del retorno cíclico en ella (2000: 21). Vicente Cabrera en Juan Benet dice: «The whole concept of journey or trip is [...] a metaphor of man's search for identity, of man's odyssey of exploration within his life and being, of his own labyrinth» (1983: 87).

El tiempo benetiano es uno de repetición eterna, custodiado y preservado por Numa. Véase este ejemplo acerca del doctor Sebastián, personaje condenado a vivir recluido, amargado y frustrado por los recuerdos de sus pérdidas, en Volverás a Región: 
Filosofía, intertextualidad y postmodernismo: la influencia de Friedrich Nietzsche en la obra...

En cambio, su madre... quizá era la que disparaba; no era una venganza sino la reanudación del ciclo crónico, la fiesta saturnal de una mente arcaica que exigía el regressus ad uterum para borrar los errores y descarríos de la edad presente y preparar el nacimiento de una nueva raza (1967: 153).

Es volver al origen y comenzar de nuevo la historia de cero, inmaculada. Un imposible, la única solución ante una irrealidad trágica sin escapatoria.

7.- El superhombre o un Zaratustra revertido y mostrado como un hombre que según Nietzsche, en Así habló Zaratustra,

[...] es un puente y no una meta [...] (2009b: 240);

$[\ldots]$ un puente entre lo animal y lo divino, «[...] superior a nosotros: aunque nosotros seamos reyes. [...] el soberano en la tierra» (2009b: 291);

[...] iél es ese rayo, él es esa demencia! (2009b: 23);

[Y] el gran mediodía habrá llegado cuando el hombre se encuentre a mitad de camino entre el animal y el superhombre y celebre su camino hacia el ocaso como su suprema esperanza: pues es el camino hacia un nuevo día (2009b: 100).

Muy posiblemente Benet parte de esta idea nietzscheana o para desconfiar de su llegada y de su capacidad regeneradora y taumatúrgica o para mostrar su incapacidad de superar las fuerzas de un destino regionato maldito. Dice que el superhombre es el «hombre recto», el «superior» (1978: 47), pero también que es un producto que cree aburrido para los literatos en su artículo «Onda y corpú sculo en el Quijote» (1981: 99). Ironiza con este concepto en su artículo «Proyecto para una constitución» al compararlo con un Estado postfranquista que quiere sobrevivir promulgando una constitución, la de 1978, que tiene como artículo único el que estatuye que «[a] todo ciudadano español se le reconoce el derecho a fracasar» (1982: 15). Es un ideal de liderazgo, de fortaleza, subvertido, tal vez una crítica antifranquista e incluso de dimensiones universales.

En ciertas novelas benetianas aparecen líderes fracasados que luchan contra un destino fatídico como el tullido y mediocre general Gamallo de Volverás a Región, un rencoroso sin carácter, nefasto con las mujeres y vencedor en la guerra más por fortuna que por talento. O Eugenio Mazón, el protagonista de Herrumbrosas Lanzas, mostrado como un antihéroe, sin temperamento, variable, inconstante, maniático, sin inquietudes, arbitrario, incomprendido, lacónico, desorganizado, improvisador, nada intelectual, sin claridad en sus exposiciones, sin memoria ni capacidad analítica y fracasado en el matrimonio, con las mujeres y en los negocios: «[...] el fin de raza de una familia exhausta [...]. Como comandante en jefe [...] dejaba mucho que desear. Más que descuidar buen número de sus funciones y competencias, se negaba a intervenir en ellas [...].» (1983c, 1985 y 1986: 387-389).

8.- El sujeto como apariencia, descentrado psicológicamente, que se define por relación de poder entre una red de otros sujetos y objetos más que por situación física. Fluctúa, lo arrastran fuerzas que oscilan. Está desplazado de los centros tradicionales de poder y de estabilidad psicológica y espiritual. 
Carece de unidad, está atomizado, fragmentado, es pasivo, receptor, más efecto que causa del sueño trágico. Los más claros ejemplos de Nietzsche se encuentran en El nacimiento de la tragedia:

[...] el sueño valora justo de manera opuesta el misterioso fondo de nuestro ser, del cual nosotros mismos no somos sino su apariencia. [...] [T]anto más apremiado me siento a abrazar esa suposición metafísica de que lo en realidad existente, lo Uno originario, en cuanto instancia eternamente sufriente y llena de contradicciones, precisa a su vez de la apariencia harto placentera y de la visión arrobada para su perpetua redención (2009a: 68).

Nosotros, empero, en cuanto seres completamente cautivos e integrantes constitutivos de esta apariencia, estamos obligados a concebirla como lo que en verdad no existe, es decir, como un incesante flujo en el tiempo, el espacio y la causalidad o, dicho con otras palabras, como mera realidad empírica. [...] [C]omprendamos nuestra existencia empírica y la del mundo en general como una representación generada en todo momento por lo Uno originario primordial: entonces el sueño tendrá que aparecérsenos como la apariencia de la apariencia [...] (2009a: 68-69).

En Benet, el sueño nietzscheano es sustituido por la memoria, a la que convierte en esa apariencia. Es lo no existente sobre lo que nos sustentamos en nuestra imagen. En Una meditación dice el narrador:

[...] ¿qué puedo encontrar que me sirva de clave para encontrar la razón -ya no la justificación- ni de ser lo que fui ni lo que esperé, ni de poder esperar ya otra cosa que no ser nada ni al menos poderme anticipar al no ser nada para ser algo dejando de ser nada? (1970b: 65);

[...] [T]oda la estampa animada de un yo que en vano trataba de incorporar a mi memoria para convencerme de que sólo así podía estar seguro de vivir ahora [...] la injusta y siniestra exclusión de un verdadero vivir que tal yo y tal imagen disfrutan y sufren fundidos en uno [...]. [...] [N]o lograr nunca ser, ausente del pensamiento y la memoria como tales [...]. Y cuántas veces he tratado de presentarme la imagen cabal de esa existencia [...] (1970b: 66).

9.- La voluntad de poder de la que nos habla Nietzsche en Así habló Zaratustra (141), una que también puede ver de manera pesimista: «Todos quieren llegar al trono: su demencia consiste en creer -ique la felicidad se sienta en el trono! A menudo es el fango el que se sienta en el trono -y también con frecuencia el trono en el barro» (2009b: 64). Benet se hace eco de este tema, del fracaso para el ser humano y para la historia de las luchas de poder. El poder lo detentan en sus obras hombres que buscan satisfacer su egolatría y resarcirse de frustraciones no superadas. Por ejemplo, menciona que en 1883 Nietzsche sustituye la «filosofía del volatinero», la firme, flexible, bien equilibrada y bien preparada, por la «filosofía del martillo, el afán por el golpe brutal y desmedido -sin gracia ni preparación ni medida- que no valora otra cosa que el destrozo causado [...]» (1976a: 34). Este tema es nodular en las obras acerca de la guerra civil española en las luchas de poder entre republicanos y nacionales pero también en las «intestinas» dentro de estos bandos, tanto como en y entre clanes familiares (véanse sobre todo sus novelas Volverás a Región, Saúl ante Samuel y Herrumbrosas lanzas, así como su libro histórico La sombra de la guerra). Esa voluntad de poder se convierte en noluntad a causa de ese destino fatídico y de la impotencia que irrigan sus obras.

No necesariamente es una influencia que parte exclusivamente de Nietzsche, pero sin duda alguna un fragmento de Herrumbrosas lanzas, que pone al general Francisco Franco, al que no alude 
por su nombre, como ejemplo de líder en busca del poder y de la satisfacción personal más que de hacer algo grande y útil por su patria, está en esta línea de pensamiento (víd. Díaz Navarro, 2000: 6172):

\begin{abstract}
Ni las creencias, ni la fidelidad a la depuesta monarquía, ni la defensa de ideales mancillados por la República, ni la amistad (que no tenía) con algunos conjurados, ni el esprit de corps que pudiera unirle a buen número de cabecillas, le movieron a sumarse a la rebelión. Lo hizo por lucro. [...] No quería un triunfo rápido, pues sabía que sería efímero y, entre la victoria y el poder, optaría siempre por el último [...] (1983c, 1985 y 1986: 34).
\end{abstract}

10.- La voluntad de estilo. Nietzsche, un helenista que escribía filosofía, cree que el mundo y su existencia son y se justifican como un fenómeno estético en El nacimiento de la tragedia, como bien incide Peter Berkowitz (1995: 70). El dominio del estilo fomenta la búsqueda de la sabiduría, de la belleza y del placer, propios del «principium individuationis», el subjetivo, del que habla. Son los «impulsos estéticos»(2009a: 72) propios de Apolo y el «impulso apolíneo hacia la belleza» y el «torrente dionisiaco» de Dionisio (2009a: 72). Además, advierte que «[...] sólo como fenómenos estéticos aparecen revestidos de justificación el mundo y la existencia» (2009a: 182). Dios, para el alemán, es el creador y el destructor de la moral en busca no solo de la soberanía sino también del placer (2009a: 42).

Félix de Azúa afirma que Nietzsche es defensor del «Grand Style» (1998: 268), algo similar a las ideas de La inspiración y el estilo. Benet mismo pone a Nietzsche como ejemplo de autor preocupado por el estilo que representa y depura con belleza lo imperfecto y monstruoso del mundo y del ser. Lo opone al realismo, al naturalismo y al costumbrismo que pretenden hacer un análisis fallidamente mimético y referencial (1965: 117 y 119) con su dicción directa y expresión vulgar, popular. En contraposición a estos movimientos, antecedentes del realismo social del franquismo al que este novelista se muestra contrario y que Gutiérrez Carbajo dice que pueden ser ejemplos del «atractivo de la imperfección» con la caída del gran estilo en el siglo XIX inglés (1997: 51), Benet propone el valor del estilo. Este, según él, «[...] proporciona el estado de gracia [...]» y es «[...] una vía evidente de conocimiento, independiente y casi trascendente a ciertas funciones del intelecto [...].» (1965: 9).

Así pues, con él intenta crear una nueva versión del gran estilo con la amalgama de un lenguaje que combina lo narrativo, lo poético, lo histórico, lo científico, lo filosófico-especulativo y lo solemne y discursivo propio de la «falta de decorum», lleno de metáforas, oximorones, paréntesis y arabescos, con la ayuda de la ironía y del humor. Y esto niega que exista un puro «stream of consciousness» en los monólogos de su obra. Para ello, hay que destruir el lenguaje convencional y crear uno nuevo. Véase este fragmento benetiano:

Nietzsche y todos nuestros literatos del siglo XX que han querido transcender el lenguaje han dicho que éste no es un vehículo de expresión cabal y que tenemos que destruirlo; y que tenemos que destruir la sintaxis, la sindéresis y la gramática porque la realidad transciende a esa composición tan logística, tan artificiosa y factual que hemos heredado (1997: 105). 
En conclusión, en forma de parodia y hacia una apuesta personal de texto sincrético que combina lo narrativo, lo poético, lo histórico y lo filosófico, Benet absorbe a Nietzsche tanto de manera directa, con citas evidentes, como indirecta, transformando las ideas dentro de su discurso y de su diégesis. Esta penetración forma parte del espíritu del «pastiche» postmoderno ya que está combinada con otras influencias. Esto se evidencia más en la expresión que en la influencia en sí, ya que toda combinación de palimpsestos es natural y consustancial a la obra artística. Benet recoge de Nietzsche las constantes polares de su filosofía, enunciadas anteriormente, para crear un universo ficcional regido por la esencia de lo trágico y por la incapacidad del ser humano para encontrar un líder o superhombre, que la experiencia demuestra que anhela más el poder y la satisfacción individual que la sabiduría o que el bien colectivo, el cual nos ayude a superar un destino adverso gobernado por unas fuerzas inmemoriales e invisibles que nada tienen que ver con el concepto cristiano monoteísta de divinidad.

Cada uno de diferente manera propone que no hay manera de reducir el conocimiento o la razón a unas reglas o leyes inmutables y que no existe una actitud unificada entre los seres humanos, los cuales se dividen en hombres fracasados que prefieren la acción o la pasión, la cual nunca pueden culminar. Para ambos, tampoco el saber se puede fijar ni en el interior de la ipseidad o de lo inmanente, descentrados ante las caprichosas luchas de poder que se producen sobre la faz de una tierra gobernada y depurada por la tragedia, la auténtica de las guerras y la depurada como género dramático-literario, la cual hace que la historia sea eternamente cíclica, predeterminada por un destino adverso, en su marcha hacia la ruindad, hacia la ruina y hacia la muerte. La filosofía de Nietzsche ha penetrado en Benet para diluirse y para convertirse en una muy original obra literaria.

\section{Bibliografía citada}

AA. VV. (1989): Especial Juan Benet, en El Urogallo, 35 (marzo), pp. 31-77.

Alonso, S. (1983): La novela en la transición. Madrid, Puerta del Sol/Ensayo.

AlLEN, G. (2000): Intertextuality. London and New York, Routledge.

Bakhtin, M. M. (1981): The Dialogic Imagination. Four Essays. Michael Holquist, ed., Caryl Emerson and Michael Holquist, trans., Austin, University of Texas Press.

BAROJA, P. (2006): César o nada (Las ciudades I). Madrid, Alianza Editorial.

BARTHES, R. (1974): S/Z. Richard Howard, trans., New York, Hill and Wang.

Benet, J. (1965): La inspiración y el estilo. Con dos textos de Carmen Martín Gaite. Madrid, Alfaguara, 1999.

_ (1967): Volverás a Región. Víctor García de la Concha, com. Barcelona, Destino, 1996.

- (1970a): Puerta de tierra. Barcelona, Seix Barral.

- (1970b): Una meditación. Barcelona, Seix Barral.

— (1972): Un viaje de invierno. Diego Martínez Torrón, ed. Madrid, Cátedra, 1989.

_ (1973): La otra casa de Mazón. Barcelona, Seix Barral. 
Filosofía, intertextualidad y postmodernismo: la influencia de Friedrich Nietzsche en la obra...

_ (1976a): El ángel del señor abandona a Tobías. Barcelona, La Gaya Ciencia.

- (1976b): En ciernes. Madrid, Taurus.

— (1977): En el estado. Juan Benet, pról. y col. Vicente Molina-Foix, pról. Javier Marías, epíl. Madrid, Santillana (Alfaguara), 1999.

_ (1978): Del pozo y del Numa (Un ensayo y una leyenda). Barcelona, La Gaya Ciencia.

- (1980): El aire de un crimen. Barcelona, Planeta.

_ (1980): Saúl ante Samuel. John B. Margenot III, ed., Madrid, Cátedra, 1994.

- (1981): La moviola de Eurípides y otros ensayos. Madrid, Taurus.

- (1982): Sobre la incertidumbre. Barcelona, Ariel.

— (1983a): «Esferodoxia», en Artículos: 1962-1977. Vol 1. Madrid, Ediciones Libertarias, pp. 109-113.

(1983b): «Ingeniería e intimidad», en Artículos: 1962-1977. Vol 1. Madrid, Ediciones Libertarias, pp. 159-166.

— (1983c, 1985 y 1986): Herrumbrosas lanzas. Madrid, Santillana (Alfaguara), 1998.

(1987): Otoño en Madrid hacia 1950. Madrid, Alianza Editorial.

(1989): En la penumbra. Madrid, Santillana (Alfaguara), 1994.

— (1996a): Páginas impares. Madrid, Santillana (Alfaguara).

(1997): Cartografía personal. Valladolid, Cuatro. Ediciones.

(1998b): Cuentos completos. Madrid, Santillana (Alfaguara).

(1998c): Trece fábulas y media y Fábula decimocuarta, Madrid, Santillana (Alfaguara).

(1999c): La sombra de la guerra. Escritos sobre la Guerra Civil española. Gabriel Jackson, pról. Madrid, Santillana (Taurus).

BENSON, K. (1989): Razón y espíritu. Análisis de la dualidad subyacente en el discurso narrativo de Juan Benet. Stockholm, Stockholms Universitet, Romanska Institutionen.

- (2004): Fenomenología del enigma. Juan Benet y el pensamiento literario postestructuralista. Amsterdam-New York, NY, Rodopi.

Berkowitz, P. (1995): Nietzsche. La ética de un inmoralista. Madrid, Cátedra.

Bloom, H. (1973): The Anxiety of Influence. New York, Oxford University Press, 1978. (1975): A Map of Misreading. New York, Oxford University Press.

Cabrera, V. (1983): Juan Benet. Boston, Massachusetts, G. K. Hall \& Company (Twayne's World Authors Series).

Compitello, M. A. (1983): Ordering the Evidence: Volverás a Región and Civil War Fiction. Barcelona, Puvill Libros.

Chamorro, E. (1976): «Intento de aproximación a los textos de Juan Benet», en Augusto Roa Bastos

y Juan Benet, en Cuaderno de Norte. Revista Hispánica de Ámsterdam, pp. 110-120.

De AzúA, F. (1986): «El texto invisible. Juan Benet: Un viaje de invierno», en Juan Benet. Kathleen

M. Vernon, ed., Madrid, Taurus, pp. 147-157.

(1998): Lecturas compulsivas. Una invitación. Ana Dexeus, ed., Barcelona, Anagrama. 
De Lope, M. (2000): «L'écriture chronotopique de Juan Benet: L'involution de l'histoire dans le monde des origines», Sociocriticism,15/1, pp. 15-29.

DíAz NaVArro, E. (2000): La forma del enigma. (Siete ensayos sobre la narrativa de Juan Benet). Zaragoza, Colección Trópica. Anexos de Tropelías, 7.

EPPS, B. (1997): «The Cold Furnace of Desire: The Site of Sexuality in Volverás a Región», en Juan Benet. A Critical Reappraisal of his Fiction. John B. Margenot III, ed., West Cornwall, CT, Locust Hill Press, pp. 33-91.

Foucault, M. (2008): Nietzsche, la genealogía, la historia. José Vázquez Pérez, trad., Valencia, PreTextos.

FRAZER, J. G. (2011): La rama dorada: magia y religión. Elizabeth y Tadeo I. Campuzano, trad., Ciudad de México, Fondo de Cultura Económica.

GArcía PAstor, J. (1993): «El vaticinio de un alma poseída (sobre el arte citativo de Juan Benet)», Ínsula, 559-560, pp. 25-6.

García PÉrez, F. (1997): Una meditación sobre Juan Benet. Madrid, Santillana (Alfaguara).

Genette, G. (1982): Palimpsests: Literature in the Second Degree. Channa Newman and Claude Doubinsky, trans., Gerald Prince, fore., Lincoln \& London, University of Nebraska Press, 1997.

Gimferrer, P. (1976): «Notas sobre Juan Benet», en Augusto Roa Bastos y Juan Benet. Cuaderno de Norte. Revista Hispánica de Ámsterdam, pp. 96-109.

GINGERICH, S. D. (2004): «Returning to the Originary Enmity of Philosophy and Literature: Juan Benet's Del pozo y del Numa (Un ensayo y una leyenda)», Revista de Estudios Hispánicos, 38, pp. 317-340.

- (2008a): «Historia fantástica: Genre and Historiography in Juan Benet's Una tumba», Cincinnati Romance Review, 27, pp. 71-86.

- (2008b): «Telling (in) the Half-Light: Mimetic Poetics and Juan Benet's En la penumbra», Hispania, 91/3, pp. 569-578.

Gullón, R. (1994): «Una Región laberíntica que bien pudiera llamarse España», en La novela española contemporánea. Madrid: Alianza Editorial, pp. 181-194.

GutiéRrez CARBAJO, F. (1997): «La inspiración y el estilo en Benet», La página, 30, pp. 44-55.

HARVEY, D. (1989): The Condition of Postmodernity: An Enquiry into the Origins of Cultural Change. Oxford, UK. \& Cambridge, Mass., Blackwell Publishers.

Hassan, I. H. (1987): The Postmodern Turn: Essays in Postmodern Theory and Culture. Columbus, Ohio State University Press.

Herzberger, D. K. (1976): The Novelistic World of Juan Benet. Clear Creek, IN, The American Hispanist.

(1984): «The Theme of Warring Brothers in Saúl ante Samuel», en Critical Approaches to the Writings of Juan Benet. Roberto C. Manteiga, David K. Herzberger, and Malcolm Alan Compitello, eds., Juan Benet, fore., Hanover and London, Published for University of Rhode Island by University Press of New England, pp. 100-110. 
(1995): «Narrative Enigmas: History and Fiction in Juan Benet», en Narrating the Past: Fiction and Historiography in Postwar Spain. Durham and London, Duke University Press, pp. 87-115. (1997): «Juan Benet's Death», en Juan Benet. A Critical Reappraisal of his Fiction. John B. Margenot III, ed., West Cornwall, CT, Locust Hill Press, pp. 3-17.

(1999): «Nuevo historicismo: “Construyendo la disidencia: Historia y ficción en Volverás a Región de Juan Benet"», en El hispanismo en los Estados Unidos: Discursos críticos/prácticas textuales. José M. del Pino and Francisco La Rubia Prado, eds., Madrid, Visor, pp. 133-47.

IZQUIERDO, A. (2000): Friedrich Nietzsche. Madrid, EDAF.

Jameson, F. (1991): Postmodernism, or, The Cultural Logic of Late Capitalism. Durham, Duke University Press.

KristeVA, J. (1974): El texto de la novela. Jordi Llovet, trad., Barcelona, Lumen, 1981.

LaRA Rallo, C. (2007): Las voces y los ecos. Perspectivas sobre la intertextualidad. Málaga, Analecta Malacitana.

LÓPEZ LóPEZ, M. (1992): El mito en cinco escritores de posguerra (Rafael Sánchez Ferlosio, Juan Benet, Gonzalo Torrente Ballester, Álvaro Cunqueiro, Antonio Prieto). Madrid, Verbum.

LyOTARD, J. F. (1979): The Postmodern Condition. Geoff Bennington and Brian Massumi, trans. From French, Minneapolis, University of Minnesota Press, 1993.

MACHÍn LuCAS, J. (2001): «Juan Benet al trasluz: palimpsestos subversivos en Región», Cuadernos hispanoamericanos, 609, pp. 19-28. (Traducido al polaco por Barbara Jaroszuk (2007) como «Region jako palimpsest», en Literatura na świecie, 1-2/426-427, pp. 56-65).

- (2009): El primer Juan Benet (1965-1972): La forja de un estilo novelístico. Saarbrücken, VDM Verlag.

MARGENOT III, J. B. (1988): «Cartography in the Fiction of Juan Benet», Letras peninsulares, I/I, pp. $70-86$.

(1991): Zonas y sombras: Aproximaciones a Región de Juan Benet. Madrid, Pliegos.

Martínez García, P. (1996): «El paisaje como metáfora de la historia: Volverás a Región de Juan Benet y Las Geórgicas de Claude Simon», en Actas del X Simposio de la Sociedad Española de Literatura General y Comparada. Santiago de Compostela, Universidade de Santiago de Compostela, pp. 393-414.

MinARDI, A. (2010): «Las tramas de la historia entre la memoria, la utopía y la guerra: Herrumbrosas lanzas de Juan Benet y El laberinto mágico de Max Aub», en Actas del XVI Congreso de la Asociación Internacional de Hispanistas. Nuevos caminos del hispanismo... 6. Historia y política. Pierre Civil y Françoise Crémoux, eds., Madrid y Frankfurt am Main, Iberoamericana Vervuert, pp. 192-201.

(2012): Historia, memoria, discurso. Variaciones sobre algunos ensayos benetianos. Madrid, Pliegos.

Molina Ortega, A. M. ${ }^{a}$ (2007): Las otras regiones de Juan Benet. Cáceres, Universidad de Extremadura. 
356 Tropelías. Revista de Teoría de la Literatura y Literatura Comparada, 23 (2015) Jorge Machín Lucas

NAVAJAS, G. (1987): «Modernismo, posmodernismo y novela policiaca: El aire de un crimen, de Juan Benet», Monographic Review/Revista Monográfica, 3/1-2, pp. 221-30.

NiETzSCHE, F. (2009a): El nacimiento de la tragedia o helenismo y pesimismo. Germán Cano, trad. y notas, en Nietzsche. Vol. I, Germán Cano, intr., Madrid, Gredos, pp. 32-185.

(2009b): Así habló Zaratustra. Un libro para todos y para nadie. José Rafael Hernández Arias, trad. y notas, en Nietzsche. Vol. II, Madrid, Gredos, pp. 11-380.

RIFFATERRE, M. (1978): Semiotics of Poetry. Bloomington, Indiana University Press.

SobejAnO, G. (1967): Nietzsche en España (1890-1970). Madrid, Gredos, 2009.

(1986): «Saúl ante Samuel. Historia de un fratricidio», en Juan Benet. Kathleen M. Vernon, ed., Madrid, Taurus, pp. 158-176.

VAttimo, G. (1988): The End of Modernity: Nihilism and Hermeneutics in Post-Modern Culture. Jon R. Snyder, trans. and intr., Cambridge, Polity Press.

WhiTe, H. (1973): Metahistory. Baltimore \& London, The Johns Hopkins University Press. 